\title{
An Annual Money Demand Function for Pakistan: Some Further Results
}

\author{
I. U. MANGLA*
}

The paper highlights the main issues involved in the theoretical and empirical estimation of the money demand function in Pakistan. Much of the recent empirical work on money demand has used income as a scale variable. Our work seeks to assess the relevant importance of the permanent income as an argument of the demand function for money. The results of our estimation indicate that a stable money demand function exists using permanent income.

Much of the recent empirical work in the general area of monetary economics has focused on the estimation and testing of the demand function for money. We do not intend to give a survey of the whole literature since it is well documented elsewhere, e.g. Boorman [5], Goldfeld [12], Barro and Fischer [3], Feige and Pearce [8] and David Laidler [16]. Even at the risk of some oversimplification, the main issues invloved in the estimation of the demand for money are as follows: (1) Is the demand for money measured in nominal terms, proportional to the price level? (2) Should income or wealth or perhaps both be included in the demand for money function? (3) Is the rate of interest an important variable in the function? (4) Are there any significant economies of scale in money holdings? (5) What influence does the rate of inflation or its expected rate exert on the demand for money? (6) How close is the complementarity relationship between money and physical assets as suggested by McKinnon [18] in the process of economic development?

Although there has been a substantial amount of research on the money demand for developed economies, very few studies exist in the case of Pakistan. These studies, e.g. Rao and Choudary [23], Akhtar [2] and Abe, Fry et al. [1] are limited in scope. The analysis focuses only on testing the McKinnon hypothesis, using current income as the scale variable in the money demand function. This procedure is incomplete because wealth and/or permanent income, rather than current income, should appear as an argument in the demand for money function.

*The author is an Assistant Professor of Economics at the Quaid-i-Azam University, Islamabad (Pakistan). Among those who made helpful comments on an earlier draft of this paper are: Dr. Robert H. Rasche and Dr. Mark Ladenson of Michigan State University, Dr. A.R. Kemal of the PIDE and anonymous referees. However, the views expressed are those of the author alone. 
The purpose of this paper is to examine the range of issues (1) to (5) noted above, in the light of the empirical evidence from Pakistan. It re-examines the existing empirical evidence on the demand for money in Pakistan by using permanent income as a scale variable in the money demand function. Also it is important to consider as to which interest rate is the relevant determinant of the demand for money. The paper also tests whether the conventional money demand formulation is adequate to explain the monetary experience of an economy like Pakistan.

The plan of the paper is as follows. The first section briefly spells out the money demand model used conventionally for estimation purposes, while the second section discusses the methodological issues involved. The third section tests the applicability of the model to Pakistan. In discussing the results, particular emphasis is placed on nominal versus real money demand. The fourth section notes briefly the limitations of the analysis. The policy implications of the analysis form the subject matter of the fifth section. Main conclusions of the analysis presented in the paper are then briefly highlighted in the final section.

\section{MONEY DEMAND MODEL: GENERAL CONSIDERATION}

The general features of our money demand function are standard. Desired money balances, $M^{*}$ are assumed to be a function of interest rate, $r$, and a constraint variable, $X$, i.e.

$$
\mathrm{M}^{*}=\mathrm{M}(\mathrm{X}, \mathrm{r})
$$

where $\mathrm{X}$ is either GNP, permanent income or some measure of wealth. Most econometric studies deflate the nominal money demand either by the price level or population or both. This is done to isolate the effect of changes in the demand for money balances resulting from changes in the price level or population as opposed to changes in income. To test the hypothesis that the demand for money function is homogeneous of degree zero in general prices, ${ }^{1}$ desired real balances should be made invariant with respect to changes in the price level.

Several aspects of the model require clarification about: (1) the level of constraint variable $\mathrm{X},(2)$ the list of possible components of the interest rate

${ }^{1}$ The author is gratefully indebted to Prof. Syed Nawab Haider Naqvi, Director, PIDE, for drawing his attention to the distinction between absolute versus relative prices in the analysis of money demand function. In examining the economic response to changes in actual and expected rates of inflation, both empirical and theoretical models of the demand for money theoretical assertion thet if nat all prices change equiproportionately. This is based on the underlying effects on commodity demand functions can change in the same proportion, then study, Policano and Choi [21] have developed behaviour. A significant result of their analysis is that assumption of equiproportionate price change is unrealistic and that the net effect of a change in relative prices on household's money demand depends on the purchase frequencies and price elasticities of the relevant commodities. vector, $r$, and (3) the process by which actual money balances, $M$, approach their long-run equilibrium values, $M^{*}$. As to first problem, the choice of the appropriate scale variable would depend on the additional means of discriminating among different theories of the demand for money. The level of income has played an important role in the empirical tests of the transaction demand for money, e.g. Baumol [4] and Tobin [28]. Frequently, use of the wealth variable has been preferred in portfolio analysis. Friedman [9] employs the concept of permanent income in the money demand function to reconcile the cyclical and secular behaviour of velocity. In our estimation of the model for the sake of comparison, we have used nominal GNP, nominal permanent income, real income and real permanent income as the scale variables.

On the second problem, most studies contain convincing evidence that interest rate should appear in the demand for money function. In dealing with the relevant measure of the opportunity cost of holding money, however, there is still disagreement as to which measure should be used as an argument of the demand for money function. The problem stems partly from the fact that the theory provides little guidance on this issue. Our expectation is that interbank call money rate, $r_{c}$, and government bond rate, $r_{g}$, should be the important variables. On the other hand, some economists, e.g. Wong [30] and Khan [15] have argued that in developing countries rates of interest are controlled by the authorities, and do not always reflect accurately market conditions. Under these circumstances, the expected rate of inflation becomes a more appropriate proxy for the opportunity cost of holding. Again the question is empirical and can not be decided by a priori reasoning alone.

The third problem to be satisfactorily tackled would require a complete comparative static analysis. However, we have assumed throughout this paper that adjustment mechanism is instantaneous and actual money balances adjust to their desired level in one year. This is based on the view that lags are shorter, if not negligible, in the developing countries because of higher risks and uncertainties due to economic and socio-political instability and lack of a variety of financial assets available for the wealth holders to undertake portfolio switches. ${ }^{2}$

\section{METHODOLOGY}

Following general practice money stock has been treated in this paper as a proxy for the demand for money. It is assumed that the money market is always in equilibrium and the variables which appear in the demand function do not belong in the money supply function. ${ }^{3}$ If we focus on theories that emphasize the transaction motive for holding money, then the proper definition of money is not a profound problem. We have defined money as consisting of

${ }^{2}$ See for example, Park [19].

${ }^{3}$ If the money stock involving demand and supply elements simultaneously determine money stock and interest rates then we have the identification problem making the income and interest rate elasticity estimates biased. 
those assets that serve as generally acceptable media of exchange, i.e. currency in circulation and private demand deposits of commercial banks. For Pakistan, data on all scale variables appropriate for a money demand function are available only on annual basis. Our estimates are based on mid-year observations of each year over the period 1958-1971.4

Several studies on money demand have calculated the permanent income series by relating it to the consumption, e.g. Friedman [9]. In the absence of reliable estimates of consumption expenditure, we define permanent income as the following average of current and past incomes.

$$
\mathrm{Y}_{\mathrm{pt}}=.4 \mathrm{Y}_{\mathrm{t}}+.3 \mathrm{Y}_{\mathrm{t}-1}+.2 \mathrm{Y}_{\mathrm{t}-\mathrm{z}}+.1 \mathrm{Y}_{\mathrm{t}-\mathrm{s}}
$$

Rausser and Laumas [24] do not consider it to be necessary that the measure of permanent income relevant in determining consumption expenditure should also be the one which determines the demand for cash balances.

The definitions of the variables are as follows: $M_{1}$ is the domesticallyheld money stock, $r_{c}$ is the interbank call money rate at Karachi, $r_{g}$ is annual yield on long term government bonds. $Y$ is nominal GNP and $Y_{p}$ is nominal permanent income. For estimating the real money demand function, the relevant variables were deflated by the implicit GNP deflator. The data on money and GNP were taken from annual Pakistan Economic Survey; $r_{c}$ and $r_{g}$ were taken from 'Report on Currency and Finance 1971-72' [25]. All equations have been estimated using the log-linear form.

One of the primary concerns in the literature on money demand has been the stability of the estimated function. Stability of the money demand function is measured by how well the model explains movements in the dependent variable once the sample period is divided into subperiods. This is done to see whether there is any evidence of systematic long-run shifts that make the estimated relationship unsuitable for forecasting and policy purposes. Stability is measured by different methods. ${ }^{5}$ The nature of the data and the sample size make it difficult to rigorously address this question. However, the Chow test ${ }^{6}$ enables us to test whether the new observations have been generated by the same model.

\section{BASIC RESULTS}

\section{Nominal Money Demand}

All regression equations estimated in this paper use the log-linear form. The estimated coefficients, based on equation (1) of the model, using OLS are "Post 1971 data was not included due to major structural shift in the economy.

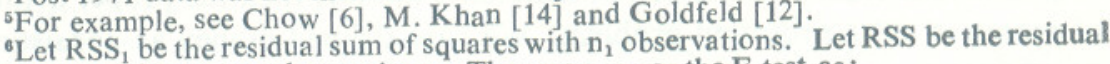
sum of squares with $n_{1}+n_{2}$ observations. Then we can use the F-test as:

$$
F=\frac{\left(\mathrm{RSS}-\mathrm{RSS}_{1}\right) / \mathrm{n}_{2}}{\mathrm{RSS}_{1} /\left(\mathrm{n}_{1}-\mathrm{k}-1\right)}
$$

given in Table $1 .{ }^{7}$ Several aspects of the results warrant comment however. The statistical fit of the equation comes out to be exceedingly close and the income and interest rate elasticities possess the anticipated signs. The coefficients of $Y_{p}$ or GNP are significantly different from zero and one at very high confidence level. The coefficients of $r_{c}$ or $r_{b}$ come close to being significant. The equilibrium elasticity of money demand with respect to the $r_{c}$ in Pakistan, evaluated at the sample mean of $r_{c}$ is -.003 . Such a low value for $r_{c}$ casts doubt on the view that money is a substitute for other short-term liquid assets. When both interest rates are included equation (3) of Table 1 , the coefficient of $r_{g}$ becomes significant.

The long-run nominal income or permanent income elasticity for Pakistan is one of the most significant results of this study. Regardless of the specification of the demand function, all estimates of this parameter lie between 1.28 and 2.00. The use of permanent income further increases the income elasticity.

On balance, the estimates of equation (1) of the model based on nominal magnitudes seem satisfactory in terms of absolute performance. The bulk of the evidence from these equations employing annual data indicates rather clearly that permanent income rather than measured income is the most relevant constraint on the equilibrium level of the demand for money balances. One aspect that deserves additional attention is the estimate of the long-run income elasticity. The results of Table 1, taken as a whole, seem to suggest that relevant income elasticity cannot be pinned down accurately, and is significantly greater than unity. As regards the existence of economies of scale in money holding, the results are comparable with those studies of long-run such as Friedman [9] and Laidler [16]. All these studies including our results suggest that economies of scale in money holding are non-existent.

\section{Real Money Demand Function}

The use of real money demand is preferred on the grounds that it seems useful to regard the nominal quantity of money as determined by conditions of supply, and the real quantity of money as determined by conditions of demand. The estimated coefficients and their t-values are reproduced in Table 2. An important similarity exists between income elasticities for both nominal and real demand functions, ranging between 1.28 and 1.53 for the current income variable and between 1.69 and 2.88 for the permanent income variable. There is no compelling reason why the permanent income elasticity of money demand should be higher than the income elasticity of money demand. ${ }^{8}$ However, the

'The single-equation models of money demand will yield unbiased estimates if the explanatory variables are exogenously determined. Demand for nominal balarces should be estimated using Two Stage Least Square (TSLS) method because of the possible causation danger of accepting such a relationship without a priori theoretical reasoning alerts us to the

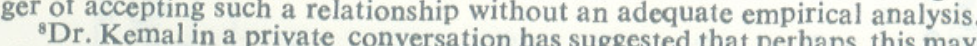

act that because permanent income increases consistently and is nothaps this may be due to the component, people adjust their real balances accordingly and therefore one would expect higher elasticity of money demand with respect to permanent income as suggested in the consumption studies.

with $n_{2}, n_{1}-k-1$ degrees of freedom. 


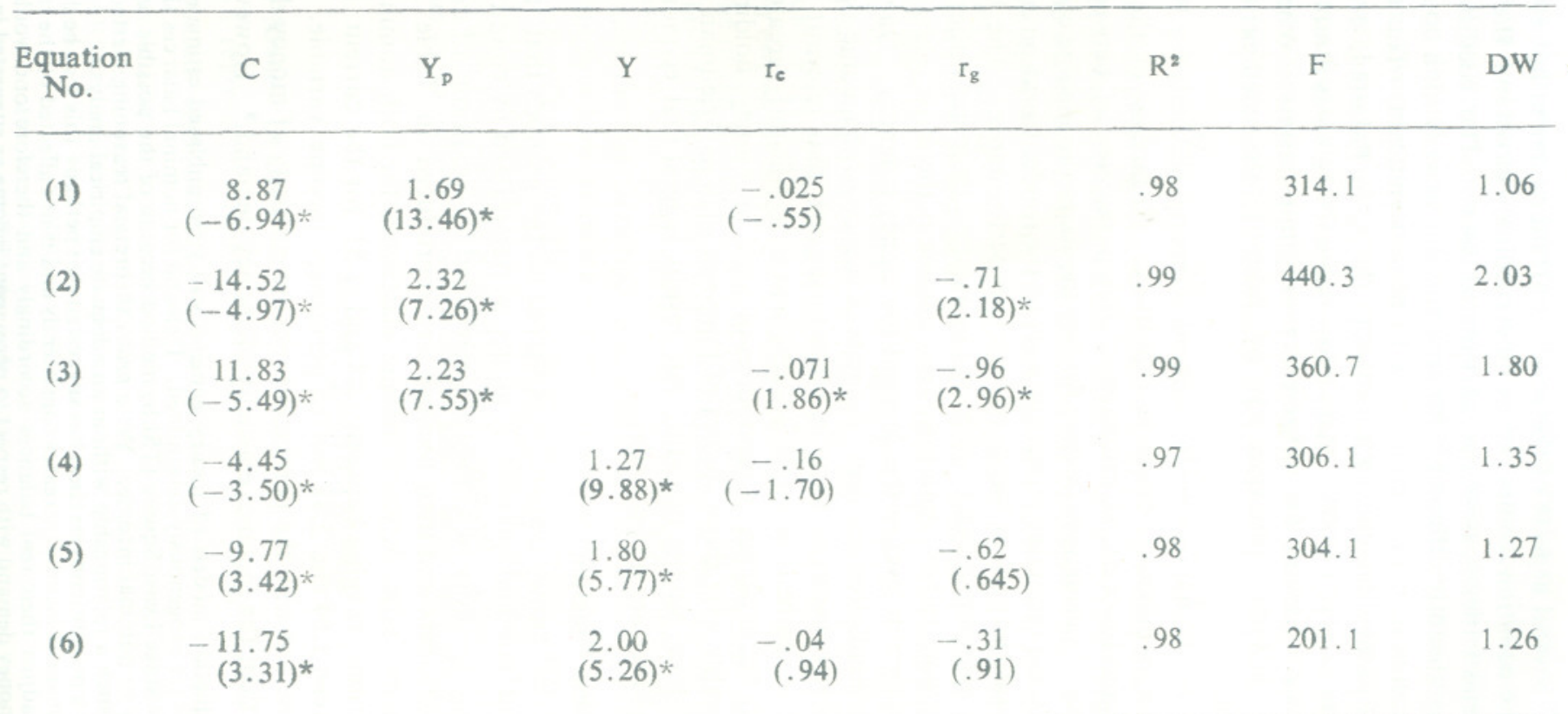

Note: All equations are estimated using log-linear form. $\mathrm{C}$ is the intercept term; $\mathrm{Y}_{\mathrm{p}}$ is nominal permanent income; $\mathrm{Y}$ is nominal GNP; $r_{c}$ is interbank call money rate; $r_{g}$ is average annual yield on Government bonds. The t-values are given in parentheses, and a $\operatorname{star}(*)$ indicates that coefficients are statistically significant at 95 percent confidence interval.

Table 2

Estimated Coefficients of the Real Money Demand Model

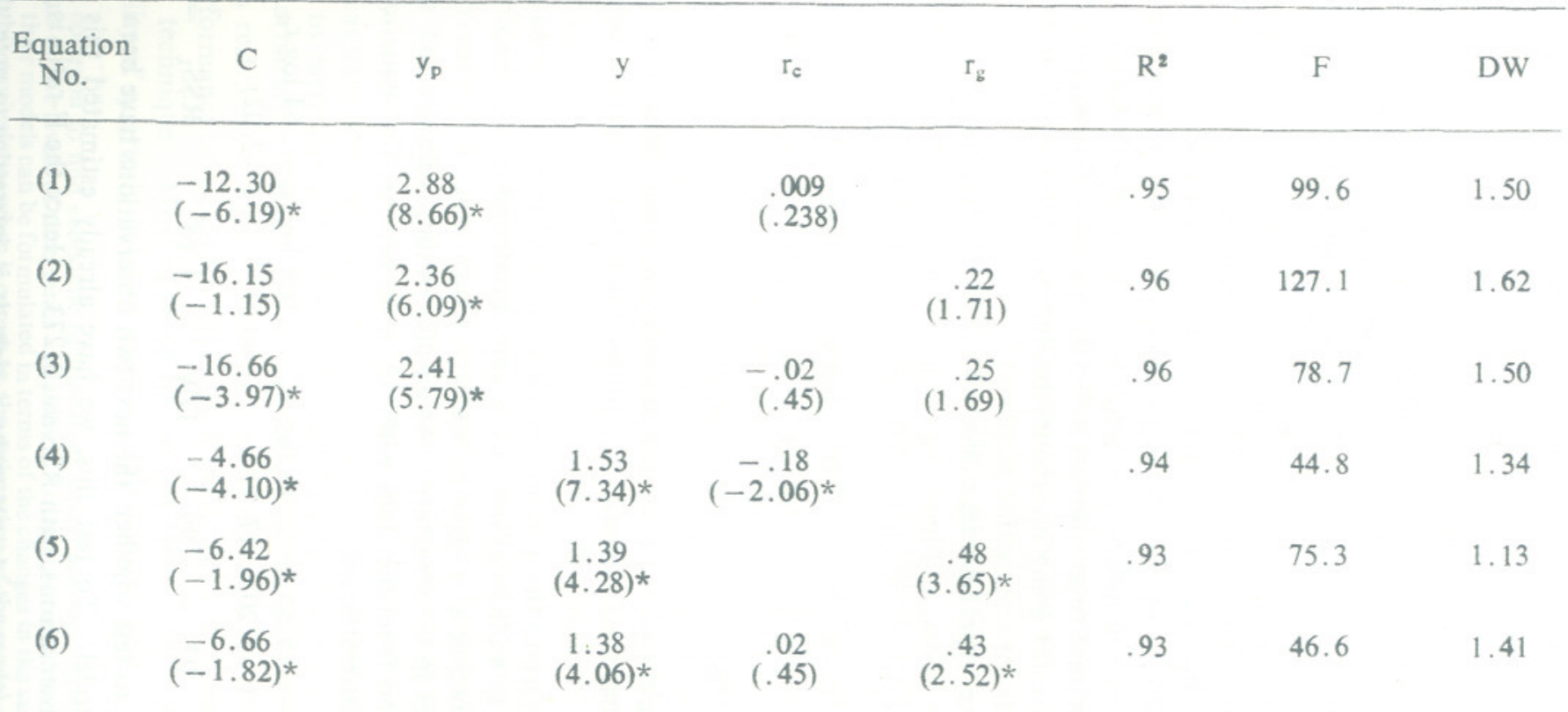

Note: $\mathrm{C}$ is the intercept term; $\mathrm{y}_{\mathrm{p}}$ is real permanent income; $\mathrm{y}$ is GNP divided by implicit price deflator; $\mathrm{r}_{\mathrm{c}}$ and $\mathrm{r}_{\mathrm{g}}$ have been defined before. The t-values are expressed in parentheses and a star $\left(^{*}\right)$ indicates that coefficients are statistically significant at 95 percent confidence interval, 
overall values of these elasticities generally greater than unity can be defended. As Friedman has pointed out:

"Much empirical evidence indicates that the income elasticity is not very different from unity. The empirical evidence seems to me to indicate that the elasticity is generally larger than unity, perhaps in the neighbourhood of 1.5 to 2.0 for economies in a period of rapid economic development, and of 1.0 to 1.5 for other circumstances. Other scholars would perhaps set it lower" [11, p. 34].

The most unexpected result in estimated real money demand equations is the wrong sign of interest rates. However, paradoxically, the $r_{g}$ coefficient is still significant. Perhaps the apparent puzzle can be solved if we keep the 'Fisherian distinction' in mind between nominal and real interest rates and the role of expected rate of inflation in holdings of real money balances. If we are willing to assume that people do not suffer from money illusion, then even with nominal interest rates going up, money holders will build up their balances to match their needs for transaction purposes. ${ }^{2}$

To test the hypothesis that demand for money function is homogeneous of degree zero in prices, and ignoring the problem of income distribution, our best fitted equation for real money balances is given below:

$$
\begin{aligned}
& \log { }^{m}=-8.62+2.08 \log \mathrm{y}-.27 \log \mathrm{r}_{\mathrm{c}}+.25 \log \mathrm{P} \\
& \begin{array}{llll}
(-2.86) \quad(4.80) \quad(-2.47) \quad(.59)
\end{array} \\
& \mathrm{R}^{2}=.96 \quad \mathrm{DW}=1.98
\end{aligned}
$$

Since the coefficient of $\log \mathrm{P}$ is insignificantly different from zero, we cannot reject the hypothesis that demand for money balances is invariant with respect to prices.

We now turn to the question of the stability of money demand function, which provides an additional test of the appropriateness of the specification of our model. However as suggested earlier, Chow test is a weaker test in detecting changes in the structure. As an illustration, consider the estimation of money demand from the data with 12 observations for equation (3) of Table 1. The estimates are:

$$
\begin{aligned}
& \log \mathrm{M}=-15.85+2.45 \log \mathrm{Y}_{\mathrm{p}}-.059 \log \mathrm{r}_{\mathrm{c}}-.64 \log \mathrm{r}_{\mathrm{g}} \\
& \begin{array}{llll}
(-5.20) & (7.39) & (-1.73) & (-2.02)
\end{array} \\
& \mathrm{R}^{2}=.99 \quad \mathrm{DW}=.1 .68 \quad \mathrm{RSS}_{1}=.00743
\end{aligned}
$$

We want to test whether the next two observations have been generated by the same model. To test this, we have already estimated this equation containing 14 observations, with RSS as .01273 . Hence the F-ratio is given by:

-Although two wrongs do not make a right it is interesting to note that similar unexpected signs of the interest rate coefficients have been obtained by Abe, Fry et al.

$$
\mathrm{F}=\frac{(.012736-.00743) / 2}{(.00743) / 8}=2.85
$$

F-value for 2 and 10 degrees of freedom at the 5 percent level of significance is 4.10. Hence we can't reject the null hypothesis. It is, therefore, safe to conclude that the last two observations came from the same structure as the first 12. The same is found true for equation (3) of Table 2.

We do not find any strong evidence that rate of inflation influenced the demand for money over this period. We regressed all real and nominal money demand equations with also $\hat{\mathrm{P}}$ (rate of change in implicit GNP deflator with respect to time) variable and found its coefficient having the expected negative sign but insignificantly different from zero. Given the focus of our study, we have not investigated McKinnon's hypothesis [18]. However, Akhtar [2] and Abe, Fry et al. [1] do obtain strong support for this theory.

\section{LIMITATIONS OF THE ANALYSIS}

So far we have analyzed the properties of essentially one specification, embodied in equation (1) of the model. We have used the most common definition of money- $\mathrm{M}_{1}$. Some writers have preferred a broader difinition such as $\mathrm{M}_{2}$, which also includes time deposits at commercial banks. Our analysis has also relied on a simple adjustment mechanism. While this is conventional in annual money demand estimation, careful consideration of the partial adjustment mechanism in money holdings should be undertaken in the short run functions. Our analysis also assumes that the costs of adjusting the pattern of asset holdings are the same for households and firms. If we were dealing with quarterly data, it may be helpful to disaggregate over classes of agents as well as over assets.

On some econometric issues, all of the estimates reported in this paper have been obtained by using OLS technique. It would have been worthwhile to estimate the model by applying the Cochrane-Orcutt technique [7] for correction of serial correlation. ${ }^{10}$ As mentioned earlier, the problem of simultaneous equation bias have been ignored. However, in the absence of a complete model, the choice to carry out a simultaneous equation estimation would have been somewhat arbitrary. Finally, the stability of the estimated coefficients has been tested in a restricted manner. Perhaps a more useful way of looking at the overall performance of equation (1) would have been the use of dynamic simulation technique. Most of these limitations stem from the nature and unavailability of quarterly data on scale variables on Pakistan.

${ }^{10}$ It is common to find economic relationships which are formulated and empirically tested in terms of the levels of time series variables. At the theoretical level, researchers recognize that their models can be formulated in terms of the changes in the variables, yet many do not admit this equivalence when it comes to the estimation of the model. See Plosser and Schwert [20]. 


\section{POLICY IMPLICATIONS}

Over the last two decades, there have been substantial changes in the role attached to money as a determinant of economic activity and the price level. A related issue involved is the prediction regarding the economies of scale in cash holdings due to optimal transaction. Another area of monetary policy, not fully explored concerns the implications of the interest rate elasticity of money demand for the effectiveness of discretionary monetary policy. Over the years, there has been a tendency to regard the effectiveness of such policy as varying inversely with the sensitivity of money demand to interest rates, other things remaining the same.

The significance of some of the questions posed at the beginning of the paper can be better understood in terms of the income and interest rate elasticities of money demand summarized in Table 3 below.

Table 3

Estimates of Elasticity of Money Demand

\begin{tabular}{|c|c|c|c|c|}
\hline & \multicolumn{2}{|c|}{ Elasticity of Money } & \multicolumn{2}{|c|}{ Demand with respect to } \\
\hline & $Y_{p}$ & $\mathrm{Y}$ & $r_{c}$ & $\mathrm{r}_{\mathrm{g}}$ \\
\hline Nominal & 2.23 & 2.00 & $\begin{array}{l}(-.07 \text { to } \\
-.04)\end{array}$ & $\begin{array}{c}(-.96 \text { to } \\
-.31)\end{array}$ \\
\hline Real & 2.41 & 1.53 & $\begin{array}{c}(-.02 \text { to } \\
.02)\end{array}$ & $\begin{array}{c}(.25 \text { to } \\
.43)\end{array}$ \\
\hline
\end{tabular}

Source: Equations (3) and (6) of Table 1 and 2.

However, only tentative policy implications can be drawn from the estimated results on the demand for money in Pakistan. The evidence brought together in the table, taken at its face value, suggests that the relationship between demand for money and some measure of wealth seems to be stable over time. The wealth variable for which permanent income is used as a proxy appears to be a superior scale variable for the demand for money function. A priori, there is no reason to prefer one way of generating a permanent income series over another. The aggregated behaviour displayed by income and/or wealth elasticities of money demand do not suggest the presence of economies of scale in cash holdings as the value of these elasticities significantly exceeds unity. However, these conclusions do not necessarily hold for different classes of income distributions.

The evidence is mixed on the relationship between the demand for money and the rate of interest and the choice between a long and short interest rate for inclusion in the demand function. Although most estimates of the interest rates elasticity tend to favour a negative relationship, the degree of responsiveness involved is very small. The small value of the elasticity of money demand with respect to a short rate casts doubt on the view that money is a substitute for other short term liquid assets in Pakistan.

An important result that emerges from the high value of elasticity of money demand with respect to government bond rate $r_{g}$ suggests that fairly broad government security markets could be developed. The significant variations in money demand due to changes in $r_{g}$ could at least provide the basis for the conduct of traditional open-market operations. ${ }^{11}$ This optimism is based on the view that the spectrum of owners of marketable government securities has observed some structural change over the last decade in Pakistan. Further work is required to study the composition of government debt before we can investigate this question. Nevertheless, security markets will always be somewhat less broad than those of the financially developed economies.

There is also reasonable evidence supporting the existence of a stable demand for money function. This is important for the conduct of monetary policy. An empirical money demand function should have implications for the behaviour of income velocity of money. However, any suggestive implications would require the study of macro framework regarding the growth rate of the productivity of the economy and behaviour of interest rates over time.

\section{CONCLUSIONS}

In the process of evaluating each of the questions raised at the beginning of this paper, a considerable amount of information has emerged from our findings. At a glance, the results suggest that equation (1) of the model seems to be doing a satisfactory job of explaining money demand, based on the statistics obtained from within the sample period. In Pakistan, the quantity of money demanded appears to be a stable function of income and relatively more stable function of permanent income. There is considerable uniformity in the coefficient of income. The income elasticity of money demand is generally greater than unity and seems to contradict what a naive quantity theorist would expect in the long-run. The demand for money function seems to be homogeneous of degree zero in general prices.

The evidence on the relevance of interest rates as an argument of the money demand function, the findings of this study do not always conform to a priori reasoning. The available results do not provide the most reliable measure of the opportunity cost of holding money. All attempts in this study include more than one interest rates proved to be unsuccessful. Nevertheless, the appropriate specification of the interest rates is more in favour of the interbank call money rate, $r_{c}$. This analysis might also suggest that in countries where interest rates are inoperative and in the absence of empirical support 
for inflation or expected inflation rate in reflecting the opportunity cost of holding money, some other proxy variable like credit restraint should be used. Perhaps more work needs to be done on this problem.

While the conventional formulation has performed well, it is possible to improve on it in a number of ways. An empirical money demand function should have implications for the behaviour of income velocity of money. As noted, the specification used for developed countries create no problems when annual data are employed. It is therefore worthwhile examining the case using quarterly data on the scale variables for the fine tuning of monetary policy and to improve the forecasting behaviour of money demand.

Received August, 1978; final version received March, 1979

\section{REFERENCES}

1. Abe, S., M. Fry, B. Min. and T. Yu. "The Demand for Money in Pakistan: Some Alternative Estimates." The Pakistan Development Review. Vol. XIV, No. 2. Summer 1975. pp. 249-257.

2. Akhtar, M.A. "The Demand for Money in Pakistan." The Pakistan Development Review. Vol. XIII, No: 1. Spring 1974. pp. 40-45.

3. Barro, J and S. Fischer. "Recent Developments in Monetary Theory." Journal of Monetary Economics. 2 (April 1976). pp. 133-167.

4. Baumol, William J. "The Transaction Demand for Cash-An Inventory Theoretic Approach." Quarterly Journal of Economics. 66 (November 1952). pp. 545-556.

5. Boorman, John. "The Evidence of the Demand for Money: Theoretical Formulation and Empirical Results." In Boorman and Havrilesky (eds.) Current Issues in Monetary Theory and Policy. AHM Publishing Corporation, Arlington Heights, Illinois. 1976. pp. 315-361

6. Chow, G. "Tests of Equality between Sets of Coefficients in Two Linear Regression." Econometrica. July 1960.

7. Cochrane, Donald and Guy H. Orcutt. "Application of Least-Squares Regression to Relationships Containing Autocorrelated Error Terms.' Journal of the American Statistical Association. 44 (March 1948). pp. 32-61.

8. Feige, E. and D. Pearce. "Substitutability Between Money and Near Monies: A Survey of the Time Series Evidence." Journal of Economic Literature. 15 (June 1977). pp. 439-446.

9. Friedman, M. "The Demand for Money-Some Theoretical and Empirical Results." Journal of Political Economy. 67 (June 1959). pp. 327-351.

10. - "The Quantity Theory of Money-A Restatement." In Studies in the Quantity Theory of Money. Edited by M. Friedman. Chicago: University of Chicago.

11. "A Theoretical Framework of Monetary Analysis." Occasional Paper 112. NBER, New York. 1971.
12. Goldfeld, Stephen M. "The Demand for Money Revisited." Brookings Papers on Economic Activity. 3(1973). pp. 577-638.

13. Keynes, John M. The General Theory of Employment: Interest and Money. New York: Harcourt, Brance and World, Inc., 1965.

14. Khan, M. "The Stability of Demand for Money Function in the U.S." Journal of Political Economy. 82 (November 1974). pp. 1205-1220.

15. Khan, M. and Aghelvi. "Inflationary Finance and Dynamics of Inflation: Indonesia." American Economic Review. June 1977.

16. Laidler, David. The Demand for Money: Theories and Evidence. (2nd ed.) New York: Dun-Donnelley, 1977.

17. Mangla, I.U. and M. Ladenson. "Short Run Forecast of Money Stock in Pakistan." The Pakistan Development Review. Vol. XVII, No. 2. Summer 1978.

18. McKinnon, Ronald I. Money and Capital in Economic Development. Washington, D.C.: Brookings Institution, 1973.

19. Park, Y.C. "The Variability of Velocity: An International Comparison," IMF Staff Papers. November 1970.

20. Plosser, C. and G. Schwert. "Money, Income, and Sunspots: Measuring Economic Relationships and the Effects of Differencing." Journal of Monetary Economics. November 1978. pp. 637-660.

21. Policano and Choi. "The Effects of Relative Price Changes on the Household's Demands for Money." Journal of Monetary Economics. November 1978. pp. 743-754.

22. Porter, R. "Narrow Security Markets and Monetary Policy: Lessons from Pakistan." Economic Development and Cultural Change. October 1965. pp. 48-60.

23. Rao and Choudary. "Demand for Money in Developing Economies." Pakistan Economic and Social Review. June 1971.

24. Rausser, G.C. and Prem S. Laumas. "The Stability of the Demand for Money in Canada." Journal of Monetary Economics. 2 (July 1976). pp. 367-380.

25. State Bank of Pakistan. Report on Currency and Finance 1971-72. 1971.

26. Teigen, Ronald L. "Demand and Supply Functions for Money in the U.S.: Some Structural Estimates.” Econometrica. 32 (October 1964). pp. 476-508.

27. ․ "Demand and Supply Functions for Money: Another Look." Econometrica. 44 (March 1976). pp. 377-385.

28. Tobin, J. "The Interest Elasticity of Transactions Demand for Cash." Review of Economics and Statistics. 38 (August 1956). pp. 241-247.

29. - "Liquidity Preference as Behaviour Towards Risk." Review of Economic Studies. 25 (February 1958). pp. 65-86.

30. Wong, C. "Demand for Money in Developing Countries," Journal of Monetary Economics. January 1977. 